$\left(R_{\mathrm{vA}} 1.60\right)$ showed ultraviolet (UV) spectrum similar to 8 -mercaptoadenosine. The reaction mixture was adjusted to $\mathrm{pH} 6$ with $2 \mathrm{~N} \mathrm{HCl}$ and nitrogen gas was passed through the solution. The solution was again adjusted to $\mathrm{pH} 7.5$ with $2 \mathrm{~N} \mathrm{NaOH}$ and concentrated to $c a .5 \mathrm{ml}$. The concentrated solution was applied to a column $(2 \times 60 \mathrm{~nm})$ of Biogel P-2. Fractions of $3 \mathrm{ml}$ were collected and fractions $23-37$ were combined. The yield was $890 \mathrm{~A}_{298}$ units $0.033 \mathrm{mmole}, 78 \%$. UV: $\lambda_{\max }^{\mathrm{pH} 2} 261,236 \mathrm{~nm} ; \lambda_{\mathrm{max}}^{\mathrm{pH}} 254 \mathrm{~nm} ; \lambda_{\max }^{\mathrm{pH} 13} 296 \mathrm{~nm} ; \lambda_{\mathrm{max}}^{\mathrm{pH} 2} 261$, $236 \mathrm{~nm} ; \lambda_{\max }^{\mathrm{pH} 7} 254 \mathrm{~nm} ; \lambda_{\max }^{\mathrm{pH} 13} 253 \mathrm{~nm}$. Paper chromatography in solvent $\mathrm{B}: R_{\mathrm{pA}}=0.40$, in solvent $\mathrm{D}: R_{\mathrm{pA}}=1.74$.

8-Mercaptoadensoine 3',5'-Cyclic Phosphate-8-Bromoadenosine-3',5'-cyclic phosphate $\left.{ }^{7}\right)(100 \mathrm{mg})$ was dissolved in a mixture of DMF $(0.3 \mathrm{ml})$ and water $(0.3 \mathrm{ml})$. Aqueous sodium hydrogen sulfide (407, $100 \mu \mathrm{l}$ ) was added to the mixture. After $15 \mathrm{hr}$ at $25^{\circ}$, paper electrophoresis showed almost complete conversion of the starting material. The reaction mixture was adjusted to $\mathrm{pH} 7$ with $2 \mathrm{~N} \mathrm{HCl}$ and nitrogen gas was passed through the solution, which was adjusted to $\mathrm{pH} 7.5$ with $2 \mathrm{~N} \mathrm{NaOH}$. The solution was applied to a column $(2 \times 50 \mathrm{~cm})$ of DEAE-cellulose (bicarbonate form). The column was eluted with triethylammonium bicarbonate buffer $(\mathrm{pH} 7.5,0.01-0.1 \mathrm{M}, 21+21)$ using linear gradient technique. Fractions (10 inl each) 58-120 were collected and evaporated. Evaporation was repeated several times with added water and final solution was lyophilized to give a powder. Yield was $76 \%$ UV: $\lambda_{\max }^{\text {pH } 1} 220,244,308 \mathrm{~m} \mu$; $i_{\max }^{\mathrm{H}_{2} \mathrm{O}} 221,245,310 \mathrm{~m} \mu: \lambda_{\max }^{\mathrm{HH} 11} 224,290 \mathrm{~nm} . \quad$ PPC: $R_{\mathrm{pA}}$ in solvent A 1.65 and in solvent B 0.65 . These properties were identical to those reported by Muneyama, et al. ${ }^{14)}$

14) K. Muneyama, R.J. Bauer, D.S. Shuman, R. K. Robins, and L.N. Simon, Biochemistry, 10, 2390 (1971).

\title{
Phosphorylation by Active Ester of Phosphoric Acid. I. Preparation and Reaction of Phenyl 8-Quinolyl Phosphate ${ }^{1)}$
}

\author{
Hiroshi Takaku and Yoshifusa Shimada \\ Dcpartment of Chemistry, Chiba Institute of Technology $y^{2)}$
}

(Received July 14, 1972)

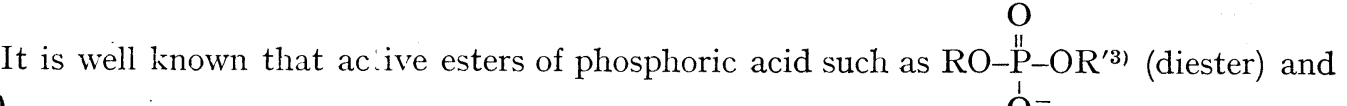
$\mathrm{O}$

$R O P_{-N}^{\prime \prime} R^{\prime} R^{\prime 4)}$ (phosph samidate) are important intermediates in the synthesis of various $\mathrm{O}^{-}$

kinds of phosphoric acid derivatives.

In the present study, the preparation of phenyl 8-quinolyl phosphate (4) and the reactions of the active diester of phosphoric acid (4) with alcohols and amines were investigated. It was considered that the phosphate $(\mathbf{4})$ would yield a reactive intermediate $\left(\mathbf{4}^{\prime}\right)$, which in turn would further react with alcohols to give diesters of phosphoric acid as shown in Chart1. The synthesis of diester of phosphoric acid can be effected successfully by this method since it reacts exclusively with nucleophilic reagents such as alcohols and amines under mild conditions.
\end{abstract}

1) Part of this work was presented at the 90th Annual Meeting of the Pharmaceutical Society of Japan, Sapporo, July 1970.

2) Location: Narashino-shi, Chiba.

3) a) W. Kampe, Chem. Ber., 98, 1031 (1965); b) W. Kampe, ibid., 98, 1038(1965); c) K.H. Scheit and IV. Kampe, ibid., 98, 1045 (1965).

4) F. Cramer, H. Schaller, and H.A. Staab, Chem. Bev., 94, 1612 (1961); H. Schaller, H.A. Staab, and F. Cramer, ibid., 94, 1621 (1961); F. Cramer and H. Schaller, ibid., 94, 1634 (1961); J.G. Moffatt and H.G. Khorana, J. Amer. Chem. Soc., 83, 649 (1961). 
The phosphorylating reagent(4)was prepared by the sequence of reaction shown in Chart 1. The phenyl phosphorodichloridate (1) reacted with one mole of 8 -quinol (2) in dry pyridine solution to give phenyl 8-quinolyl phosphorochloridate (3) which was hydrolyzed to afford phenyl 8-quinolyl phosphate (4). The phosphate (4) was isolated from the reaction mixture by extraction with carbon tetrachloride and purified by silica gel column chromatography to afford the pure phosphate (4) in $78 \%$ yield based on $\mathbf{1}$ as viscous yellowish green oil. The structure of $\mathbf{4}$ was supported by elemental analysis and infrared (IR) spectra.

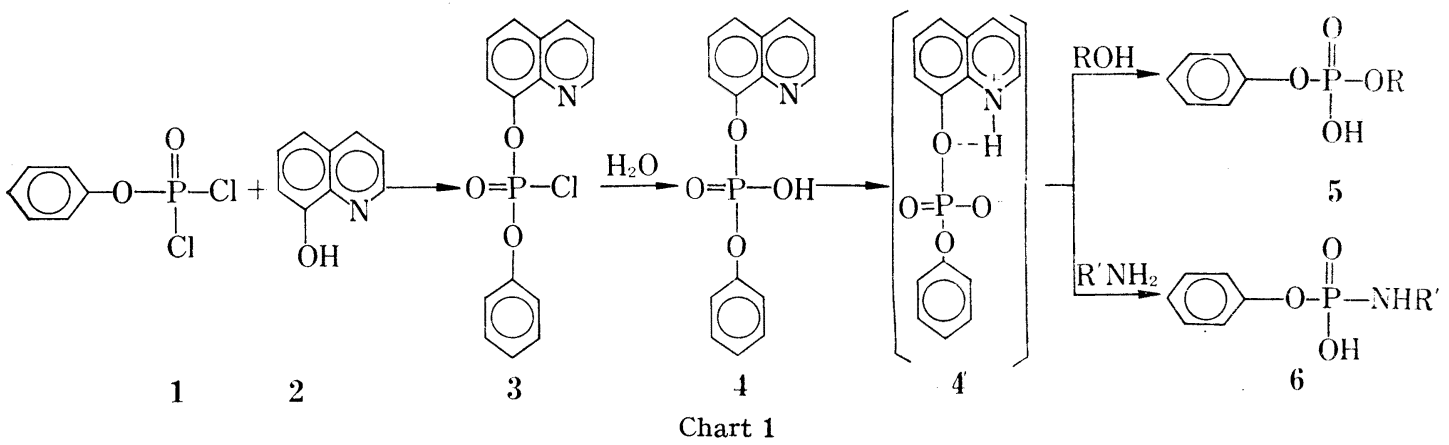

Alcohols were selectively phosphorylated with $\mathbf{4}$; for example, when 4 was treated with a slight excess of ethyl alcohol in dry pyridine at $50^{\circ}$ for $8 \mathrm{hr}$, ethyl phenyl phosphate (5b) was obtained in $72 \%$ yield as white crystal of cyclohexylammonium salt. The structure of $\mathbf{5 b}$ was supported by elemental analysis and IR spectrum which showed absorption bands at $1600(\mathrm{C}=\mathrm{C}), 1255(\mathrm{P}=\mathrm{O})$ and $1025 \mathrm{~cm}^{-1}\left(\mathrm{P}-\mathrm{O}-\mathrm{C}_{2} \mathrm{H}_{5}\right)$. The paper chromatography of the reaction mixture showed two spots of the phosphate $(\mathbf{5 b}(R f 0.66)$ and $\mathbf{4}(R f 0.79))$. According

TABLE I. Alkyl Phenyl Phosphates (5) ${ }^{a}$ )

\begin{tabular}{|c|c|c|c|c|c|c|c|c|c|c|}
\hline \multirow{2}{*}{$\begin{array}{c}\text { Compd. } \\
\text { No. }\end{array}$} & \multirow{2}{*}{$\mathrm{R}$} & \multirow{2}{*}{$\begin{array}{l}\text { Time } \\
(\mathrm{hr})\end{array}$} & \multirow{2}{*}{$\begin{array}{l}\text { Yield }^{b)} \\
(\%)\end{array}$} & \multirow{2}{*}{$\operatorname{mp}_{\left({ }^{\circ} \mathrm{C}\right)}$} & \multirow{2}{*}{$\left.R f^{c}\right)$} & \multirow{2}{*}{ Formula } & & \multicolumn{3}{|c|}{ Analysis (\%) } \\
\hline & & & & & & & & $\mathrm{C}$ & $\mathrm{H}$ & $\mathrm{N}$ \\
\hline $5 \mathbf{a}$ & $\mathrm{CH}_{3}$ & 6 & 68 & $153-154^{d)}$ & 0.60 & $\mathrm{C}_{13} \mathrm{H}_{22} \mathrm{O}_{4} \mathrm{NP}$ & $\begin{array}{l}\text { Calcd. } \\
\text { Found }\end{array}$ & $\begin{array}{l}54.40 \\
54.13\end{array}$ & $\begin{array}{l}7.73 \\
7.68\end{array}$ & $\begin{array}{l}4.78 \\
4.68\end{array}$ \\
\hline $\mathbf{5 b}$ & $\mathrm{C}_{2} \mathrm{H}_{5}$ & 8 & 72 & $110-112^{e)}$ & 0.66 & $\mathrm{C}_{14} \mathrm{H}_{24} \mathrm{O}_{4} \mathrm{NP}$ & $\begin{array}{l}\text { Calcd. } \\
\text { Found }\end{array}$ & $\begin{array}{l}55.86 \\
56.92\end{array}$ & $\begin{array}{l}8.04 \\
7.83\end{array}$ & $\begin{array}{l}4.65 \\
4.63\end{array}$ \\
\hline $5 c$ & $\mathrm{C}_{3} \mathrm{H}_{7}$ & 8 & 72 & $115^{f)}$ & 0.70 & $\mathrm{C}_{15} \mathrm{H}_{26} \mathrm{O}_{4} \mathrm{NP}$ & $\begin{array}{l}\text { Calcd. } \\
\text { Found }\end{array}$ & $\begin{array}{l}\mathbf{5 7 . 1 9} \\
56.87\end{array}$ & $\begin{array}{l}6.99 \\
6.92\end{array}$ & $\begin{array}{l}4.45 \\
4.56\end{array}$ \\
\hline $5 d$ & $\left(\mathrm{CH}_{3}\right)_{2} \mathrm{CH}$ & 17 & 79 & $164-165^{()}$ & 0.68 & $\mathrm{C}_{15} \mathrm{H}_{26} \mathrm{O}_{4} \mathrm{NP}$ & $\begin{array}{l}\text { Calcd. } \\
\text { Found }\end{array}$ & $\begin{array}{l}57.19 \\
56.92\end{array}$ & $\begin{array}{l}6.99 \\
6.71\end{array}$ & $\begin{array}{l}4.45 \\
4.52\end{array}$ \\
\hline $5 e$ & $\mathrm{C}_{4} \mathrm{H}_{9}$ & 10 & 79 & $112-113^{h)}$ & 0.75 & $\mathrm{C}_{16} \mathrm{H}_{28} \mathrm{O}_{4} \mathrm{NP}$ & $\begin{array}{l}\text { Calcd. } \\
\text { Found }\end{array}$ & $\begin{array}{l}58.41 \\
58.35\end{array}$ & $\begin{array}{l}8.58 \\
8.43\end{array}$ & $\begin{array}{l}4.25 \\
4.28\end{array}$ \\
\hline $5 f$ & $\mathrm{CH}_{3} \mathrm{CHCH}_{2} \mathrm{CH}_{3}$ & 20 & 65 & $181-182^{i)}$ & 0.72 & $\mathrm{C}_{16} \mathrm{H}_{28} \mathrm{O}_{4} \mathrm{NP}$ & $\begin{array}{l}\text { Calcd. } \\
\text { Found }\end{array}$ & $\begin{array}{l}58.41 \\
57.93\end{array}$ & $\begin{array}{l}8.58 \\
8.49\end{array}$ & $\begin{array}{l}4.25 \\
4.09\end{array}$ \\
\hline $5 \mathrm{~g}$ & $\mathrm{CH}_{2} \mathrm{C}_{6} \mathrm{H}_{5}$ & 20 & 70 & $143-144^{j)}$ & 0.71 & $\mathrm{C}_{19} \mathrm{H}_{26} \mathrm{O}_{4} \mathrm{NP}$ & $\begin{array}{l}\text { Calcd. } \\
\text { Found }\end{array}$ & $\begin{array}{l}62.86 \\
62.84\end{array}$ & $\begin{array}{l}7.22 \\
7.31\end{array}$ & $\begin{array}{l}3.86 \\
3.95\end{array}$ \\
\hline $5 \mathbf{h}$ & $\mathrm{CH}_{2} \mathrm{C}_{6} \mathrm{H}_{4} \mathrm{NO}_{2}(p)$ & b) 20 & 50 & $187-190^{k)}$ & 0.68 & $\mathrm{C}_{19} \mathrm{H}_{25} \mathrm{O}_{6} \mathrm{~N}_{2} \mathrm{P}$ & $\begin{array}{l}\text { Calcd. } \\
\text { Found }\end{array}$ & $\begin{array}{l}55.93 \\
55.67\end{array}$ & $\begin{array}{l}6.18 \\
6.05\end{array}$ & $\begin{array}{l}6.86 \\
6.83\end{array}$ \\
\hline
\end{tabular}

a) The compounds were isolated as a monocyclohexylammonium salt.

b) Yields were based on phenyl 8-quinolyl phosphate (4).

c) Paper chromatography was carried out by ascending technique using Toyo Roshi No. 50 paper. Solvent system used was: isopropyl alcohol, conc. ammonium hydroxide, water $(8: 1: 1(\mathrm{v} / \mathrm{v}))$.

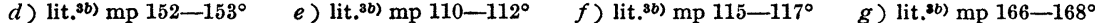

$\begin{array}{llll}\text { h) } \text { lit. }^{3 b)} \mathrm{mp} 110^{\circ} & \text { i) } \text { lit. }^{3 b)} \mathrm{mp} 180^{\circ} & \left.j \text { ) lit. }{ }^{3 b}\right) \mathrm{mp} 143-144^{\circ} & k \text { ) lit.5) } \mathrm{mp} 188-190^{\circ}\end{array}$

5) F. Cramer and G. Weimann, Chem. Ber., 91, 336 (1961). 
to this method, various alkyl phenyl phosphates (5) were obtained in high yields. These results are summarized in Table I. Of various solvents ${ }^{6)}$ examined, it was found that the yield of $\mathbf{5}$ increased when pyridine is used as the solvent.

On the other hand, when phenyl 8-quinolyl phosphate (4) was treated with amines on a similar manner to that described above, several phenyl phosphoramidates $(\boldsymbol{6})$ were obtained in almost quantitative yields. These compounds were shown to be identical with authentic samples prepared by 2-pyridyl ester of phosphoric acid. ${ }^{36)}$

In conclusion, phosphorylation of alcohols by phenyl 8-quinolyl phosphate (4) affords the corresponding diesters of phosphoric acid in good yields under mild condition. Further, these phosphates were analytically pure by treating the reaction mixture with conventional organic technique.

\section{Experimental}

Alcohols, amines and solvents were purified and dried by ordinary procedures. Phosphoryl chloride was freshly distilled before use. Paper chromatography was carried out by ascending technique using Tokyo Roshi No. 50 paper. Solvent system used was: isopropyl alcohol, concentrated ammonium hydroxide, water $(8: 1: 1(\mathrm{v} / \mathrm{v}))$. Hanes-Isherwood reagent ${ }^{7)}$ was used for the detection of spots.

Phenyl 8-Quinolyl Phosphate (4)—To a solution of $2.12 \mathrm{~g}(0.01 \mathrm{~mole})$ of phenyl phosphorodichloridate (1) in $10 \mathrm{ml}$ of dry pyridine was added, dropwise, a solution of 8-quinol (2) (1.45 g, $0.01 \mathrm{~mole})$ in $10 \mathrm{ml}$ of dry pyridine with stirring at $0^{\circ}$ over a period of about $1 \mathrm{hr}$. The stirring was continued for $9 \mathrm{hr}$ under cooling. The pyridinium chloride was removed by filtration. The filtrate was poured with stirring into $20 \mathrm{ml}$ of pyridine containing $0.36 \mathrm{ml}(0.02 \mathrm{~mole})$ of water at temperature below $10^{\circ}$. After concentrating the mixture, the residue was extracted with $90 \mathrm{ml}$ of carbon tetrachloride. The solution was washed with water and dried over anhydrous sodium sulfate. After removal of the solvent, the residue was passed through column of Wacogel C-200 $(100-200$ mesh $)(10 \times 400 \mathrm{~mm})$ by using a mixture of chloroform and methanol (8:2 $\mathrm{v} / \mathrm{v}$ ) for elution. The eluent was concentrated in vacuo to give $2.11 \mathrm{~g}(78 \%)$ of phenyl 8-quinolyl phosphate (4) as viscous green yellowish oil. Rf 0.79 . IR $\nu_{\max }^{\mathrm{rl1m}} \mathrm{cm}^{-1}: 1620-1500(\mathrm{C}=\mathrm{C}$ and $\mathrm{C}=\mathrm{N}), 1260(\mathrm{P}=\mathrm{O})$ and $1220\left(\mathrm{P}-\mathrm{O}-\mathrm{C}_{a \mathrm{ryl}}\right)$. Anal. Calcd for $\mathrm{C}_{15} \mathrm{H}_{12} \mathrm{O}_{4} \mathrm{NP}: \mathrm{C}, 59.85 ; \mathrm{H}, 4.02 ; \mathrm{N}, 4.65$. Found: C, 59.67; $\mathrm{H}, 4.48$; $\wedge, 4.78$.

Ethyl Phenyl Phosphate (5b)—A solution of $2.70 \mathrm{~g}$ ( 0.01 mole) of phenyl 8-quinolyl phosphate (4) and $2.34 \mathrm{ml}(0.05 \mathrm{~mole})$ of ethyl alcohol in $10 \mathrm{ml}$ of dry pyridine was allowed to stand at $50^{\circ}$ for $8 \mathrm{hr}$. After removal of the solvent by evaporation, the residue dissolved in $20 \mathrm{ml}$ acetonitrile and then $2.14 \mathrm{ml}$ of cyclohexylamine was added to the solution. The mixture was allowed to stand in a refrigerator overnight. The precipitate was collected by filtration and recrystallized from acetone-petroleum ether $(5: 1 \mathrm{v} / \mathrm{v})$. The corresponding monocyclohexylammonium salt of ethyl phenyl phosphate (5b) was obtained in $2.16 \mathrm{~g}(72 \%)$ yield as white crystal, mp $\left.110-112^{\circ}\left(1 \mathrm{it} .{ }^{3 b}\right) \mathrm{mp} 110-112^{\circ}\right)$. Rf 0.66 . IR $\nu_{\max }^{\text {Nujol }} \mathrm{cm}^{-1}: 1600 \quad(\mathrm{C}=\mathrm{C}), 1255$ $(\mathrm{P}=\mathrm{O})$ and 1025 (P-O-Calkyl). Anal. Calcd for $\mathrm{C}_{14} \mathrm{H}_{24} \mathrm{O}_{4} \mathrm{NP}: \mathrm{C}, 55.86 ; \mathrm{H}, 8.04 ; \mathrm{N}, 4.65$. Found: C, 56.92; $\mathrm{H}, 7.83 ; \mathrm{N}, 4.63$.

In a similar manner, the diesters $\mathbf{5}$, such as $\mathbf{5 a}, \mathbf{5 c}, \mathbf{5 d}, \mathbf{5 e}, \mathbf{5 f}, \mathbf{5 g}$ and $\mathbf{5 h}$ were obtained in high yields as shown in Table I.

Phenyl Phosphoroanilidate (6a)—A solution of $2.70 \mathrm{~g}(0.01 \mathrm{~mole})$ of the phosphate 4 and $4.72 \mathrm{~g}(0.05$ mole) of aniline in $10 \mathrm{ml}$ of dry pyridine was allowed to stand at $50^{\circ}$ for $7 \mathrm{hr}$. After removal of pyridine and excess aniline by evaporation, the resulting oily residue was dissolved in $50 \mathrm{ml}$ of acetone-ether (1:1 $\mathrm{v} / \mathrm{v}$ ) and then $2.14 \mathrm{ml}$ of cyclohexylamine was added to the solution. The mixture was allowed to stand in a refrigerator overnight. The white crystalline compound undissolved in the solvent was washed with acetone and petroleum ether, to give $2.57 \mathrm{~g}(74 \%)$ of the monocyclohexylammonium salt of $6 \mathrm{a}$ as white crystal, mp $198^{\circ}$ (lit. ${ }^{3 b}$ ) $\mathrm{mp} 197^{\circ}$ ). Rf 0.67. Anal. Calcd. for $\mathrm{C}_{18} \mathrm{H}_{25} \mathrm{O}_{3} \mathrm{~N}_{2} \mathrm{P}: \mathrm{C}, 51.77 ; \mathrm{H}, 6.95 ; \mathrm{N}, 8.03$. Found: C, 50.98; H, 7.08; N, 7.84.

Phenyl Phosphoromorpholidate (6b)—A solution of $2.70 \mathrm{~g}(0.01 \mathrm{~mole})$ of 4 and $4.35 \mathrm{~g}(0.05 \mathrm{~mole})$ of morpholine in $15 \mathrm{ml}$ of dry pyridine was allowed to stand at $70^{\circ}$ for $16 \mathrm{hr}$. The reaction mixture was worked up as the manner described above to afford $2.62 \mathrm{~g}(81 \%)$ of the pure monocyclohexylammonium salt of $6 \mathbf{b}$ as white powder, mp $192-193^{\circ}$ (lit. $\left.{ }^{3 b}\right) 193-194^{\circ}$ ). Rf 0.60. Anal. Calcd. for $\mathrm{C}_{16} \mathrm{H}_{27} \mathrm{O}_{4} \mathrm{~N}_{2} \mathrm{P}: \mathrm{C}, 56.20 ; \mathrm{H}$, $7.95 ; \mathrm{N}, 8.18$. Found: C, $56.04 ; \mathrm{H}, 7.75 ; \mathrm{N}, 8.46$.

6) In the cases of dimethylformamide and acetonitrile, alkyl phenyl phosphates (5) were obtained in lower yields.

7) C.S. Hanes and F.A. Isherwood, Nature, 164, 1107 (1949). 